\title{
Commentary
}

\section{Low-cost sensors, an interesting alternative for air quality monitoring in Africa}

\author{
Farid Rahal (1) \\ Laboratory of Sciences, Technology and Process Engineering, University of Sciences and Technology of Oran, \\ Mohamed Boudiaf, BP 1505 El M’Naouer, Oran, Algeria, farid.rahal.dz@gmail.com
}

https://doi.org/10.17159/caj/2020/30/2.9223

In Algeria, the lack of continuous measurement of air pollution is a real problem that hinders studies, strategies and decisionmaking to fight against this phenomenon. Indeed, the pollution measurement networks installed by the public authorities in the main urban centers of the country (Rahal et al., 2014) are no longer operational. This situation in Algeria is just one example among many in developing countries where the monitoring of air quality is in a deplorable state (Kumar et al., 2019), because this monitoring is a costly policy, which requires sufficient and sustainable financial means. Furthermore, the technical skills to maintain and operate the instrumentation of measuring equipment are scarce.

In Africa, the ground based air quality monitoring is often sparse, short term, piecemeal and where most of these campaigns are to test new technologies, and thus the scarce resources are not often targeted towards the local problems but rather at the external project priorities (Mbandi, 2020). Despite the investments made by several African countries to acquire conventional air quality monitoring networks, these infrastructure are often inoperative after few years because their maintenance is expensive.

Indeed, an economic barrier prevents the establishment of air pollution-monitoring networks in many African countries. An alternative (or supplement) to the traditional air quality monitoring infrastructure can potentially come from the recent development in electrochemical sensor technologies for air quality monitoring. These sensors are generally small, consume little energy, cost between 10 and 1,000 US Dollars, and measure concentrations of all major air pollutants. Compared to large, high-end solutions costing more than 100,000 US Dollars, lowcost sensors are particularly useful for large-scale static and mobile deployments (Maag et al., 2018; Rai et al., 2017; Baron et al., 2017).

Furthermore, low-cost air pollution sensors have been successfully integrated into various long-term deployments to provide detailed information on air pollution for quantitative studies and utilities (Yi et al., 2015).

Electrochemical air quality sensors have the potential to fill the gap left by conventional monitoring of air pollution. The cost and size of air pollution sensors is decreasing, which means that it is now possible to use portable and inexpensive air pollution analyzers (Gunawan et al., 2018).

The low costs of these components make it possible to deploy several copies to assess air pollution at a finer spatial resolution than could be possible with traditional monitoring setups. This solution is interesting for developing countries, which do not have air quality monitoring networks and the necessary budgets for the acquisition of conventional analyzers.

Several implementations have been done in this area in Africa, for example in Senegal (Ngom et al., 2018), Mauritius (Khedo et al., 2017), and Algeria (Rahal et al, 2020).

However, we should no longer stay at the experimental stage but move to an operational level with a dense network of sensors where the continuously measured pollutants concentrations would be shared on an African portal dedicated to air quality. Air pollution can travel long distances depending on the nature of the pollutants and their lifespan in the atmosphere. Pollutant emissions in one country can move to another neighboring country. Therefore, it is essential that air quality data was shared and accessible to all stakeholders in the field of air pollution in Africa.

The pooling of African resources in terms of measurement means, data and scientific skills in the field of air quality could lead to a synergy in line with one of the ideals of Pan-Africanism, which encourages the practice of solidarity between African peoples (Kassabo, 2009).

Africa's industrialization is moving rapidly (Pezzini et al., 2019). The development potential of the African continent is enormous. However, if this development follows the same path of Western countries, our continent will suffer many of the same adverse environmental impacts. In particular, a poor air quality.

It is necessary to do not repeat the same mistakes as the Western countries where industrialization and changing lifestyles have generated a lasting air pollution problem with major impacts on national budgets, through increased health impacts, decreased productivity and adverse impacts on the provision of ecosystem services. In Europe, it has been estimated that complying with WHO (World Health Organization) air quality guidelines can 
save 31 billion euros per year which 19 million euros due to hospitalizations. This estimate includes direct and/or indirect costs (Conti et al., 2020).

The recent COVID-19 pandemic has shown that health risks are accentuated by poor air quality. Indeed, there has been a close correlation between regions with worse air pollution and diffusion of the virus (Sterpetti, 2020). The combination between air pollution and meteorological conditions with high relative humidity, low wind speed and fog, trigger a take-off of viral infectivity (Coccia, 2020a).

The related risks with air pollution are becoming larger, it becomes urgent to reduce the gap of Africa in air quality monitoring.

Low-cost electrochemical sensors can effectively contribute to this, provided that a comprehensive strategy to fight atmospheric pollution in Africa is put in place by mobilizing all African resources in this area.

The other aspects of this strategy would be to establish pollutant emissions inventories in Africa, to develop air quality modeling in order to establish forecasts and carry out scenario studies aimed at facilitating the choice of the best policies to protect the environment and the health of African citizens against poor air quality.

\section{References}

Baron, R. and Saffell, J., 2017. 'Amperometric gas sensors as a low cost emerging technology platform for air quality monitoring applications: A review'. ACS sensors, 2(11):1553-66. https://doi.org/10.1021/acssensors.7b00620

Coccia, M., 2020. 'The effects of atmospheric stability with low wind speed and of air pollution on the accelerated transmission dynamics of COVID-19'. International Journal of Environmental Studies, 16:1-27. https://doi.org/10.1080/00207233.2020.18029 37

Conti, S., Ferrara, P., D’Angiolella, L.S., Lorelli, S.C., Agazzi, G., Fornari, C., Cesana, G. and Mantovani, L.G., 2020. 'The economic impact of air pollution: a European assessment'. European Journal of Public Health, 30. https://doi.org/10.1093/eurpub/ ckaa165.084

Gunawan, T.S., Munir, Y.M.S., Kartiwi, M. and Mansor, H., 2018. 'Design and implementation of portable outdoor air quality measurement systemn using arduino'. International Journal of Electrical and Computer Engineering, 8(1):280. https://doi. org/10.11591/ijece.v8i1.pp280-290

Kassabo, L.D., 2009. 'Le système africain de sécurité collective régionale à l'ère de l'Union Africaine'. Ph.D. thesis. University of Padova, Italy.
Kumar, A. and Gurjar, B.R., 2019. 'Low-Cost Sensors for Air Quality Monitoring in Developing Countries-A Critical View'. Asian Journal of Water, Environment and Pollution, 16(2):65-70. https://doi.org/10.3233/AJW190021

Khedo, K.K. and Chikhooreeah, V., 2017. 'Low-cost energyefficient air quality monitoring system using wireless sensor network'. Wireless Sensor Networks-Insights and Innovations. IntechOpen. https://doi.org/10.5772/intechopen.70138

Maag, B., Zhou, Z. and Thiele, L., 2018. 'A survey on sensor calibration in air pollution monitoring deployments'. IEEE Internet of Things Journal, 5(6):4857-70. https://doi.org/10.1109/ JIOT.2018.2853660

Mbandi, A.M., 2020. 'Air Pollution in Africa in the time of COVID-19: the air we breathe indoors and outdoors'. Clean Air Journal, 30(1):1-3. https://doi.org/10.17159/caj/2020/30/1.8227

Ngom, B., Seye, M.R., Diallo, M., Gueye, B. and Drame, M.S., 2018, July. 'A Hybrid Measurement Kit for Real-time Air Quality Monitoring Across Senegal Cities'. 2018 1st International Conference on Smart Cities and Communities (SCCIC) (pp. 1-6). IEEE. https://doi.org/10.1109/SCCIC.2018.8584551

Pezzini, M. and Minsat, A., 2019. 'L'industrialisation de l'Afrique nécessite une approche continentale en association avec les entrepreneurs locaux'. Annales des Mines-Realites industrielles (No. 3, pp. 8-12). FFE. https://doi.org/10.3917/rindu1.193.0008

Rahal, F., Benharrats, N., Blond, N., Clappier, A. and Ponche, J.L., 2014. Modelling of air pollution in the area of Algiers City, Algeria. International Journal of Environment and Pollution, 54(1):32-58. https://doi.org/10.1504/IJEP.2014.064049

Rahal, F., Rezak, S. and Benabadji N., 2020: In press. 'Evaluation of the impact of the COVID-19 pandemic on photochemical pollution in urban areas'. Environmental Health Engineering and Management Journal. 7(4).

Rai, A.C., Kumar, P., Pilla, F., Skouloudis, A.N., Di Sabatino, S., Ratti, C., Yasar, A. and Rickerby, D., 2017. 'End-user perspective of low-cost sensors for outdoor air pollution monitoring. Science of The Total Environment, 607:691-705. https://doi.org/10.1016/j. scitotenv.2017.06.266

Sterpetti, A.V., 2020. 'Lessons learned during the COVID-19 virus pandemic'. Journal of the American College of Surgeons, 230(6):1092-3. https://doi.org/10.1016/j.jamcollsurg.2020.03.018

Yi, W.Y., Lo, K.M., Mak, T., Leung, K.S., Leung, Y. and Meng, M.L., 2015. 'A survey of wireless sensor network based air pollution monitoring systems'. Sensors, 15(12):31392-427. https://doi. org/10.3390/s151229859 